\title{
Communication Channels and Constraint of Beef Cattle Farmers on Adoption of Artificial Insemination Technique in Dharmasraya Regency, West Sumatera
}

\author{
Ediset Ediset $^{1 *}$, Jaswandi Jaswandi ${ }^{2}$, Amrizal Anas ${ }^{1}$, and Aditya Alqamal Alianta ${ }^{1}$ \\ ${ }^{1}$ Department Socio-Economic, Faculty of Animal Science, Universitas Andalas \\ ${ }^{2}$ Department Technology and Animal Production, Faculty of Animal Science, Universitas Andalas \\ *Corresponding author.Email: ediset@ansci.unand.ac.id
}

\begin{abstract}
The research aimed to investigate the communication channel and constraint of beef cattle farmers on adoption of artificial insemination technique in ex-transmigrant area, Dharmasraya Regency, West Sumatera. The survey method was used that supported by field observation. The population was the farmers in Dharmasraya Regency, which determined sixty-four farmer respondents from five farmers' groups representing five areas (Karya Tama, Koto Agung, Sungai Atang, Padang Bintungan, and Sungai Kalang). The data analysed with quantitative descriptive that showed in percentages and scores through simple formulas and Lickert Scales. The result showed that the communication channel used by beef cattle farmers to adopt artificial insemination technique was the personal communication. It interpreted that the farmer prefers to communicate with inseminators officers directly. No one of the respondents used mass media as a communication channel. On the other hand, the significant constraint factor during adoption of artificial insemination was cultural factors. It showed by lack of trust by farmers in the Extention officers and in the success of artificial insemination.
\end{abstract}

Keywords: Agricultural extention, Artificial insemination, Communication channel, Communication constraint, Innovation adoption.

\section{INTRODUCTION}

Dharmasraya Regency is one of the transmigration destinations in West Sumatra since 1983. The Government provides transmigrants with cattle. And until now, it is still occupied intensively as part of the family business to support the household economy. Meta et al. [1] said that implementing the transmigration program had helped transmigrants to establish communities in their trans areas. Nowadays, Dharmasraya Regency, set as one of central cattle development in West Sumatera.

In 2020, Dharmasraya Regency had 42,356 head of cattle and 8,874 household farmers [2]. Ediset and Heriyanto [3] stated Dharmasraya Regency has potential as central cattle development because it has supportive natural and human resources. Based on that circumstance, Dharmasraya Regency could be determined as a developing area to increase the capacity of cattle (Kapasitas Penambahan Populasi Ternak Ruminansia "KPPTR") and household farmers.

The effort on cattle business developing in Dharmasraya Regency needs the adoption of innovations related to raising cattle. One of innovations is, artificial insemination technique that aim to increase the cattle population and repair the quality of cattle genes. It might not be implemented well because of the internal and external factors of farmers. One of those factors might be the communication channels used by farmers to get information related to artificial insemination. On the other hand, personal factors, cultural factors, physical factors, and environmental factors could be the factors that constrain the adoption of artificial insemination. If the constraint factors can be solved, it could raise the adoption rate of artificial insemination. The increase of artificial insemination adoption could achieve the purpose of increasing the population and repairing the gene quality of cattle. Based on that explanation, this research aimed to 
investigate the communication channel used by the farmers to access the information related to artificial insemination and its constraint that inhibits the farmers from adopting the artificial insemination technique.

\section{MATERIAL AND METHODS}

\subsection{Material}

The research was conducted in Dharmasraya Regency. The Government determined this regency as an area for Gertak Birahi Inseminasi Buatan (GBIB) or a program for artificial insemination in West Sumatera.

\subsection{Methods}

The research was a survey, a method supported by observation, collecting data, and inductive thinking to collect general descriptions of objects and get accurate information related to the topic [4]. The respondent was sixty-four household farmers who join to five different farmer groups in five districts in Dharmasraya Regency, who determined with proportional sampling.

The channel that used by farmers collected with observation and depth interviews. The questionnaire with the Lickert scale was used to investigate the constraint during communication (personal, cultural, physical, and environmental factors). It was also complemented by secondary data from Dharmasraya Agricultural Office. The data is presented in the table and categorised into four categories with the range scale formula below [5]. Then, the data analysed descriptive quantitative.

Range Scale $=\frac{\text { Maximum Scale Score-Minimum Scale Score }}{\text { Total of Categories }}$

Based on the formula above, the categories showed in Table 1 below:

Table 1. The motivation and constraint range score that determined based on the range scale formula.

\begin{tabular}{|l|l|}
\hline Scale Score & Constraint Variable \\
\hline $162-194$ & Significantly Constraint \\
\hline $130-161$ & Constraint \\
\hline $97-129$ & $\begin{array}{l}\text { Non-significantly } \\
\text { Constraint }\end{array}$ \\
\hline $64-96$ & Insignificantly Constraint \\
\hline
\end{tabular}

\section{RESULTS AND DISCUSSION}

\subsection{The communication channel usage in artificial insemination innovation adoption}

The result of communication channels that used by farmers to access an information regarding artificial insemination is showed in table 2 below:

Table 2. The percentage of communication channels usage by the farmers

\begin{tabular}{|l|l|l|l|}
\hline No & Channel & N & $\%$ \\
\hline 1 & Personal Channel & 34 & 53.13 \\
\hline 2 & $\begin{array}{l}\text { Personal and Group } \\
\text { Meeting }\end{array}$ & 30 & 46.88 \\
\hline 3 & Mass Media & 0 & 0 \\
\hline
\end{tabular}

Based on Table 2 above, the farmers in Dharmasraya Regency did not use mass media to get information related to artificial insemination. The farmers tend to use personal channel and group meetings as a medium to get information and brainstorming. It is contradictory with Saleh [6] opinion that stated the behaviour of cattle farmers changing. They usually use interpersonal channels but then are changed to mass media such as television and newspapers to get information about farming activities. The result becomes reasonable, and the farmers did not use mass media as a medium to get information because of a lack of content related to farming activities, especially information related to artificial insemination. It does come back to a primitive era; the farmers should use more mass media to improve their knowledge and help them adapt to social changes to run their role as a renewal agent toward a modern citizen [7].

\subsection{The communication constraint on artificial insemination innovation adoption}

The result of communication constraints on adoption of artificial insemination technique showed in Table 3 below: Table 3 showed that the biggest constraint on adoption of artificial insemination technique was cultural factors. It indicated by a lack of trust in Extention officers and a lack of belief that artificial insemination will succeed. It proves that not only the economic factor affects the adoption of innovation but also the social factor. 
Table 3. Communication constraint variables on artificial insemination innovation adoption

\begin{tabular}{|c|c|c|c|}
\hline No & Communication Constraint Factors & Score & Categories \\
\hline \multirow[t]{4}{*}{1} & Constraint on personal factors: & 149.67 & Constraint \\
\hline & Extention officers and farmers attitude & 130 & Constraint \\
\hline & Extention officers and farmers intimacy & 147 & Constraint \\
\hline & Extention officers and farmers prejudice & 172 & Significantly Constraint \\
\hline \multirow[t]{4}{*}{2} & Constraint on cultural factors: & 161.67 & Significantly Constraint \\
\hline & Communication skills of Extention officers & 121 & Non-significantly Constraint \\
\hline & Farmers trust on Extention officers & 177 & Significantly Constraint \\
\hline & Farmers believing in the success of artificial insemination & 187 & Significantly Constraint \\
\hline \multirow[t]{4}{*}{3} & Constraint on physical factors: & 137.00 & Constraint \\
\hline & Distance of Extention officers residence & 121 & Non-significantly Constraint \\
\hline & Communication channels & 122 & Non-significantly Constraint \\
\hline & Type of communication media & 168 & Significantly Constraint \\
\hline \multirow[t]{4}{*}{4} & Constraint on environmental factors & 153.00 & Constraint \\
\hline & Comfort in communicating & 182 & Significantly Constraint \\
\hline & Surround disturbing & 92 & Insignificantly Constraint \\
\hline & Extention officers time availability & 185 & Significantly Constraint \\
\hline
\end{tabular}

In their research, Hiko et al. [8] stated that social factors significantly affected the adoption of innovation in the agricultural sector. Gudykunst [9] added that innovation adoption is also affected by cultural factors. It divided into four conceptual filters that can be inhibitors in communication consisting of cultural constraint (individualistic-collectivistic rate), socio-culture constraint (membership on the social group and social identity), psycho-social constraint (stereotype, ethnocentrism, prejudice), and environmental constraint (the attitude toward physical environment, circumstances, and psychologic environment).

\subsubsection{Constraint on personal factors}

The prejudice of Extension officers and farmers was a significant constraint during communication in artificial insemination adoption. Extension officers were prejudiced that the farmers had no desire to adopt artificial insemination. It showed by the lack of interest of farmers during the meeting. While the farmers also had a prejudice that the extension officers just came to do their job without giving the reason to the farmers why this artificial insemination should be adopted. It showed a lack of intimacy between Extension officers and the farmers. According to [10], the constraint on communication felt by farmers was caring and intimacy, prejudice, differential of expectation and needed.

\subsubsection{Constraint on cultural factors}

The significant constraint showed by farmers' trust and belief in the success factor of artificial insemination. The farmers considered what kind of benefit they would achieve when artificial insemination adopting. Then, it becomes reasonable because the farmers were apprehensive about it. According to [11], the factors that affected farmers to adopt technology directly affect their farming business, suitability, and farmers' perception of the influence of media or interpersonal information.

\subsubsection{Constraint on physical factors}

Type of communication media was a significant factor that constraint during artificial insemination adoption. It occurs because of the lack of utilisation of mass media such as television, radio, newspaper, or even the internet. Except for smartphone because it used as communication media between the farmers. Farmers should use the mass media more often to increase the success of the artificial insemination rate. According to Anty [12], the farmers in Indonesia already access 
information from electronic media beside of personal media and newspapers.

\subsubsection{Constraint on environmental factors}

The way of communication and time availability by Extension officers was significantly constraint during artificial insemination adoption dissemination. It was hard to match the schedule between the Extension officers and farmers to do discussion, which caused discomfort during communication. Discomfort condition should reduce to increase the effectivity of communication during the meeting. Rosana and Saleh [13] the meeting must also provide demonstrations from extension officers, which farmers feel more valued and mitigate the constraint during communication.

\section{CONCLUSION}

Based on those results, the Dharmasraya Regency farmers used personal channels as their communication channel to access the information of artificial insemination. They did not use any mass media for communication. The significant constraint during communication artificial insemination adoption was in cultural factors. It showed by lack of trust of farmers in the Extension officers and in the success of the artificial insemination program.

\section{AUTHORS' CONTRIBUTIONS}

Every author contributed in this research as researcher, data analyst, and editor of this article. We declare that there are no conflicts of interest regarding the publication of this article.

\section{ACKNOWLEDGMENT}

The authors would like to thank Rector of Universitas Andalas through Institute of Research and Community Service Universitas Andalas for funding our research with contract number: T/35/UN.16.17/PT.01.03/PanganRD/2021, in 30 March 2021.

\section{REFERENCES}

[1] E. Meta, Megawati, and A. Fitrisia, "Kesejahteraan Masyarakat Transmigrasi di Kenagarian Panyubarangan Kabupaten Dharmasraya," Redaksi J. Kronologi, vol. 1, no. 1, pp. 3-18, 2019, [Online]. Available: http://repository.unp.ac.id/24416/1/AZMI FITRIA-TRANSMIGRASI.pdf.

[2] (Badan Pusat Statistik) BPS, "Kabupaten Dharmasraya Dalam Angka 2021," Dharmasraya Regency, 2021.

[3] Ediset and E. Heriyanto, "Analisis Potensi
Wilayah Dharmasraya untuk Pengembangan Sapi Potong dan Kaitannya Dengan Pemberdayaan Ekonomi Masyarakat," $J$. Peternak. Indones., vol. 14 (Oktobe, no. 3, pp. 425-432, 2012.

[4] I. M. Wirartha, Metodologi Penelitian Sosial Ekonomi. Yogyakarta: CV Andi Offset, 2006.

[5] A. Irianto, Pengantar Pangan dan Gizi. Jakarta: Penebar Swadaya, 2004.

[6] A. Saleh, “Tingkat Penggunaan Media Massa dan Peran Komunikasi Anggota Kelompok Peternak dalam Jaringan Komunikasi Penyuluhan Sapi Potong," Media Peternak., vol. 29, no. 2, pp. 107-120, 2006.

[7] M. B. Bungin, Sosiologi Komunikasi: Teori, Paradigma, dan Diskursus Teknologi Komunikasi di Masyarakat. Jakarta: Kencana Prenada Media Group., 2006.

[8] M. S. Hiko, W. Mosisa, and A. Dinku, "Determinants of adoption of agricultural extension package technologies by smallholder households on sorghum production: Case of Gemechis and Mieso districts of West Hararghe Zone, Oromia Regional State, Ethiopia," J. Agric. Ext. Rural Dev., vol. 12, no. 3, pp. 62-75, 2020, doi: $10.5897 /$ jaerd2020.11322.

[9] W. B. Gudykunst and Y. Y. Kim, Communication With Strangers, An Approach to Intercultural Communication. New York: McGraw-Hill, 1997.

[10] B. Bulkis, "Hambatan Komunikasi Yang Dirasakan Petani Selama Pembinaan Petani Padi (Oriza Sativa) Di Desa Oesao Kabupaten Kupang," J. Mat. Sains dan Teknol., vol. 19, no. 1, pp. 25-36, 2018, doi: 10.33830/jmst.v19i1.125.2018.

[11] K. S. Indraningsih, "Effects of Extension to Farmers 'Decision in Adopting Integrated Farming Technology," Agro Ekon., vol. 29, no. 1, pp. 1-24, 2011.

[12] K. Anty, "Hubungan antara Jaringan Komunikasi dengan Sikap Petani terhadap SUTPA 1 Sistem Usaha Tani Berbasis Padi Berorientasi Agribisnis (Kasus 2 Kelompok Tani pada Sebuah Desa di Kecamatan Ciranjang Kabupaten Cianjur Propinsi Jawa Barat,” IPB University, 2002.

[13] E. Rosana and A. Saleh, "Hambatan-hambatan Komunikasi yang Dirasakan Peternak dalam Pembinaan Budidaya Sapi Potong di Kabupaten Ogal Ilir," vol. 8, no. 1, 2010, doi: 10.29244/jurnalkmp.8.1. 